Int. J. Dev. Biol. 55: 455-465

doi: $10.1387 / \mathrm{ijdb} .103223 \mathrm{ps}$

\title{
Role of laminins in physiological and pathological angiogenesis
}

\author{
PATRICIA SIMON-ASSMANN*, GERTRAUD OREND, ELMINA MAMMADOVA-BACH, \\ CAROLINE SPENLÉ and OLIVIER LEFEBVRE \\ INSERM, U682 and Université de Strasbourg, Strasbourg, France
}

\begin{abstract}
The interaction of endothelial cells and pericytes with their microenvironment, in particular with the basement membrane, plays a crucial role during vasculogenesis and angiogenesis. In this review, we focus on laminins, a major family of extracellular matrix molecules present in basement membranes. Laminins interact with cell surface receptors to trigger intracellular signalling that shapes cell behaviour. Each laminin exerts a distinct effect on endothelial cells and pericytes which largely depends on the adhesion receptor profile expressed on the cell surface. Moreover, proteolytic cleavage of laminins may affect their role in angiogenesis. We report in vitro and in vivo data on laminin-111, $-411,-511$ and -332 and their associated signalling that regulates cell behaviour and angiogenesis under normal and pathological conditions. We also discuss how tissue-specific deletion of laminin genes affects the behaviour of endothelial cells and pericytes and thus angiogenesis. Finally, we examine how coculture systems with defined laminin expression contribute to our understanding of the roles of laminins in normal and pathological vasculogenesis and angiogenesis.
\end{abstract}

KEY WORDS: laminin, basement membrane, vasculogenesis, angiogenesis, cancer

\section{Introduction}

The lumen of blood vessels is lined by endothelial cells (EC) that interact with a subendothelial basement membrane (BM) that is composed of a complex of several matrix proteins (Fig. 1; Eble and Niland, 2009), and contains growth factors and proteases. The interaction of EC with this microenvironment, especially with the BM components, plays an essential role during angiogenic processes (Ingberg, 1992). During development, blood vessels are formed by two distinct processes described as vasculogenesis and angiogenesis. Vasculogenesis characterizes the generation of vessels from mesodermally derived angioblasts. Angiogenesis describes the formation of vessels through sprouting from a preexisting plexus (Risau and Flamme, 1995). Both events involve cell migration, proliferation and extracellular matrix (ECM) remodelling. Angiogenesis is also an essential event in tumour growth and metastasis. Similar to physiological angiogenesis, tumour angiogenesis is regulated by BM molecules in particular upon break-down and reconstitution of the vascular BM during tumour progression. Cells within a tumour can promote angiogenesis, e.g. by secretion of soluble and insoluble angiogenic factors as well as by modulating protease activities. In addition to soluble factors such as growth factors and chemokines that can support or inhibit angiogenesis, matrix molecules of the BM also play a decisive role in angiogenesis. For example the interaction of EC with intact collagen IV promote angiogenesis whereas proteolytic fragments of collagen IV and other collagens counteract this process (for reviews see Kalluri, 2003; Davis and Senger, 2005; Hallmann et al., 2005).

In this review we will focus on the role of LM in vasculogenesis and angiogenesis in normal tissue homeostasis and diseases. LM are multifunctional matrix molecules that are widely expressed forming the major scaffold of the BM (Yurchenco and Patton, 2009). LM display organ, site and developmental specificity (Miner and Yurchenco, 2004). They are cross-shaped trimers which are assembled into a triple-stranded coiled-coil structure. Up to 15 distinct

\footnotetext{
Abbreviations used in this paper: $\mathrm{BM}$, basement membrane; CAM, chick chorioallantoic membrane assay; EC, endothelial cells; ECM, extracellular matrix; EHS, Engelbreth-Holm-Swarm; FGF, fibroblast growth factor; FGFR, fibroblast growth factor receptor; LM, laminin; MMP, matrix metalloproteinase; PDGF-(BB), platelet-derived growth factor-(BB); PDGF-R $\beta$, platelet-derived growth factor receptor $\beta$; PTFE, polytetrafluoroethylene; TGF $\beta$, transforming growth factor $\beta$; VE-cadherin, vascular endothelial-cadherin; VEGF, vascular endothelial growth factor; VEGFR, vascular endothelial growth factor receptor.
}

\footnotetext{
*Address correspondence to: Patricia Simon-Assmann. INSERM, U682, 3 avenue Molière, 67200 Strasbourg, France. Fax: 33-(0)3-88-26-35-38. e-mail: Patricia.Simon-Assmann@inserm.fr - web: http://u682-inserm.u-strasbg.fr
}

Final, author-corrected PDF published online: 27 July 2011. 
isoforms have been described today and the functional differences of all LM is not well understood (Durbeej, 2010) (Fig. 1). Integrins, dystroglycan, syndecans and Lutheran are cellular receptors for LM (Barczyk et al., 2009; Durbeej, 2010). The globular domains located in the $\mathrm{N}$ - and $\mathrm{C}$-terminus of the LM $\alpha$ chains are critical for interactions with cellular receptors which trigger intracellular signalling (Suzuki et al., 2005).

Determining the function of specific LM isoforms by genetic knockout experiments turned out to be difficult. In particular, early lethality was encountered upon knock-out of several $\alpha, \beta$ and $\gamma$ chains (Gustafsson and Fässler, 2000; Li et al., 2003; Rozario and DeSimone, 2010). Moreover, partial compensation by other isoforms masks the function of the knocked out isoform (SimonAssmann et al., 2010). Furthermore, since LM are heterotrimeric molecules, it is difficult to assign a conclusive function to a particular $\alpha \beta \gamma$ combination upon deletion of a single chain by antibody staining. For example an anti-pan-LM antibody, that recognizes either the $\alpha 1, \beta 1$ or $\gamma 1$ chain, detects 11 distinct isoforms. Yet, specific single chain antibodies had been raised and are now available. They allowed to decipher expression of specific LM isoforms in blood vessels (Sixt et al., 2001; Patarroyo et al., 2002; Hallmann et al., 2005). In most tissues, only LM-411 and LM-511 are found in the endothelial BM (Hallmann et al., 2005). Since only certain LM isoforms are present in vascular BMs, it is assumed that they

TABLE 1

\section{ROLE OF LAMININS IN ANGIOGENESIS - EXPERIMENTAL APPROACHES AND BIOLOGICAL RESPONSES}

Experimental approach
Purified $L M-111$
Collagen assay
Embryoid body assay
CAM assay
Overexpression in human cancer cells
Xenografting in nude mouse
Peptide IKVAV
Cell adhesion assay
In vitro and in vivo Matrigel assays
CAM assay
Zymography
Peptide A10, A13, A55, A64, A118, A119, A124, A203
Matrigel assay
Aortic ring assay
Boyden chamber assay
Peptide $A G 73$
CAM and aortic ring assay
Immunoblotting
RGD peptide
Cell adhesion assay
Matrigel assay
Zebrafish with mutated Lama1

Mouse with mutated Lama1, and mouse with conditional Lama1 knockout

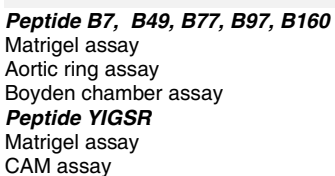

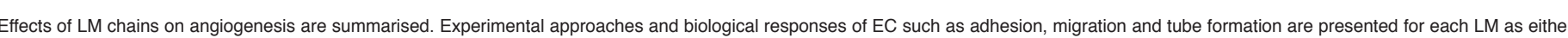

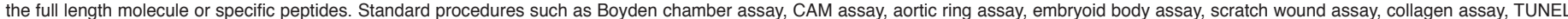

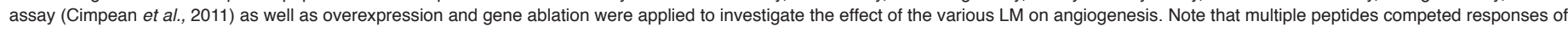
cells toward LM-111 within Matrigel.

\begin{tabular}{|c|c|}
\hline $\begin{array}{l}\text { Biological response } \\
\text { Laminin } \alpha 1 \text { chain }\end{array}$ & Reference \\
\hline $\begin{array}{l}\text { Tube formation } \\
\text { Angiogenesis } \\
\text { Angiogenesis }\end{array}$ & Dixelius et al. 2004 \\
\hline Increased tumour angiogenesis & De Arcangelis et al., 2001 \\
\hline $\begin{array}{l}\text { EC attachment } \\
\text { Inhibition of tubulogenesis, inhibition of angiogenesis } \\
\text { Angiogenesis }\end{array}$ & $\begin{array}{l}\text { Grant et al. } 1992 \text { and } 1994 \\
\text { Kibbey et al. } 1992\end{array}$ \\
\hline Activation of proteolytic enzymes & $\begin{array}{l}\text { Stack et al. } 1993 \\
\text { Faisal Khan and Falcone, } 1997\end{array}$ \\
\hline $\begin{array}{l}\text { Tube inhibition } \\
\text { Vessel sprouting } \\
\text { Migration (A10, A55, A64) }\end{array}$ & $\begin{array}{l}\text { Malinda et al. } 1999 \\
\text { Kuratomi et al. } 1999\end{array}$ \\
\hline $\begin{array}{l}\text { Angiogenesis, vessel sprouting } \\
\text { Interaction with Syndecans }\end{array}$ & $\begin{array}{l}\text { Mochizuki et al. } 2007 \\
\text { Hoffman et al. } 1998\end{array}$ \\
\hline $\begin{array}{l}\text { EC attachment, EC spreading } \\
\text { Tube inhibition } \\
\text { Delayed EC differentiation } \\
\text { Defect in hyaloid vasculature } \\
\text { Defect in vessel formation } \\
\text { Defect in hyaloid vasculature, Impaired angiogenesis } \\
\text { Laminin } \beta 1 \text { chain }\end{array}$ & $\begin{array}{l}\text { Aumailley et al. } 1991 \\
\text { Grant et al. } 1989 \\
\text { Semina et al. } 2006 \\
\text { Edwards et al. } 2010\end{array}$ \\
\hline $\begin{array}{l}\text { Tube inhibition } \\
\text { Vessel sprouting } \\
\text { Migration (B160) }\end{array}$ & Malinda et al. 1999 \\
\hline $\begin{array}{l}\text { Tube inhibition } \\
\text { Inhibition of angiogenesis }\end{array}$ & $\begin{array}{l}\text { Kubota et al.1988, Grant et al. } 1989 \\
\text { Sakamoto et al. } 1991\end{array}$ \\
\hline $\begin{array}{l}\text { Laminin } \gamma 1 \text { chain } \\
\text { Tube inhibition } \\
\text { EC attachment, vessel sprouting } \\
\text { Angiogenesis (C25, C30, C38, C64) }\end{array}$ & Ponce et al. 1999 \\
\hline $\begin{array}{l}\text { Laminin } \alpha \mathbf{4} \text { chain } \\
\text { EC adhesion, EC migration, } \\
\text { Tube inhibition } \\
\text { Stimulation of angiogenesis }\end{array}$ & $\begin{array}{l}\text { Gonzales et al. } 2001 \\
\text { Gonzalez et al. } 2002\end{array}$ \\
\hline $\begin{array}{l}\text { EC spreading, EC migration } \\
\text { Tube formation }\end{array}$ & Li et al. 2006 \\
\hline $\begin{array}{l}\text { Inhibition of proliferation } \\
\text { Enhanced apoptosis } \\
\text { Impaired microvessel maturation } \\
\text { Increased tumor angiogenesis }\end{array}$ & $\begin{array}{l}\text { DeHahn et al. } 2004 \\
\text { Thyboll et al. } 2002 \\
\text { Zhou et al. } 2004\end{array}$ \\
\hline $\begin{array}{l}\text { Laminin } \alpha 5 \text { chain } \\
\text { Reduced vessel stability }\end{array}$ & Miner et al.1998; Miner, 2008 \\
\hline $\begin{array}{l}\text { EC attachment } \\
\text { EC migration }\end{array}$ & Doi et al. 2002 \\
\hline No effect & Dixelius et al. 2004 \\
\hline
\end{tabular}


are critical for maintenance of vessel stability and/ or integrity. Formation of new vessels during angiogenesis requires degradation of the BM, a process in which EC are exposed to other LM isoforms such as LM-111, that are usually not expressed or weakly expressed in most healthy tissues but are present in the abnormal microenvironment. Most of the data reported in the present review, and summarized in Table 1, are based on in vitro and in vivo models that were applied to elucidate the angiogenic properties of LM (Cimpean et al., 2011).

\section{In vitro angiogenesis assays with reconstituted basement membrane proteins}

The first LM discovered was isolated from the matrix of the murine EHS tumour (Engelbreth-Holm-Swarm) and is now designated as LM-111 (Timpl et al., 1979). The antibody raised against the EHS LM preparation, formed by $\alpha 1, \beta 1$ and $\gamma 1$ chains, was considered to exclusively recognize LM-111 which turned out to be wrong. Indeed, several LM isoforms share the $\alpha 1, \beta 1$ or $\gamma$ chain and therefore can be recognized by the anti-pan laminin antibody. Yet, by using $\alpha 1$ chain-specific antibodies it had been observed that $\alpha 1$-containing LM are not ubiquitously expressed in BM but exhibit a limited distribution. This is in contrast to $\beta 1 \gamma 1$ containing LM forming trimers with $\alpha$ chains other than $\alpha 1$ that are found ubiquitously in BM. LM-111 is expressed during early embryogenesis (Sasaki et al., 2002) where it plays an essential role in developing kidney tubules, lung alveoli and submandibular glands (Ekblom et al., 2003). LM-111 is essential for embryogenesis due to its expression in the extraembryonic Reichert's BM. Thus it is not surprising that Lama1 knockout mice die by embryonic day 7 (Miner et al., 2004; Alpy et al., 2005). Despite a restricted expression in the adult, LM-111 is expressed in polarized tissues such as the mammary gland and the intestine, which suggests an essential role in cellular polarization in tissues with a high turnover and remodelling (Simo et al., 1991, Streuli et al., 1995; Virtanen et al., 2000; Simon-Assmann et al., 2010). But how LM-111 would induce or regulate polarization is unknown.

Several studies have characterised the behaviour of cells when placed on natural or reconstructed BM. The most widely used example is Matrigel, a commercialized cell culture matrix, extracted from the EHS tumour. EC cultured on Matrigel cease to proliferate, align and form capillary-like structures (Kubota et al., 1988; Pauly et al., 1992). Furthermore, Matrigel has been demonstrated to support the formation of tubules from EC in vitro as well as vascular networks when implanted into mice (Passaniti et al., 1992; Garrido et al., 1995). One major application of Matrigel is to support tumour grafting in murine xenograft experiments (Kleinman and Martin, 2005). Yet, due to several growth factors and other components in Matrigel, conclusions to what molecule the result relates to should be taken with caution (Hughes et al., 2010). As LM-111 is the major glycoprotein found in Matrigel, several studies aimed to define its precise function in regulating angiogenesis. In particular, LM-111 recombinant proteins, proteolytic fragments and synthetic peptides have been generated and were used to identify and characterize functional domains of the molecule.

\section{Pro-angiogenic properties of sequences within the laminin a1 chain}

It has been shown that matrix-derived synthetic peptides, corresponding to active sites in proteins, could have biological activities on their own. Using synthetic peptides from the $\alpha 1$ chain, Grant et al., (1992, 1994) had demonstrated that an IKVAV (lle-Lys-ValAla-Val) containing-peptide (Fig. 2) promoted EC migration and invasion into Matrigel and increased angiogenesis in the chick chorioallantoic membrane assay (CAM). The angiogenic activity of this IKVAV-containing peptide was further confirmed in an in vivo model when the peptide was co-injected with melanoma cells

A

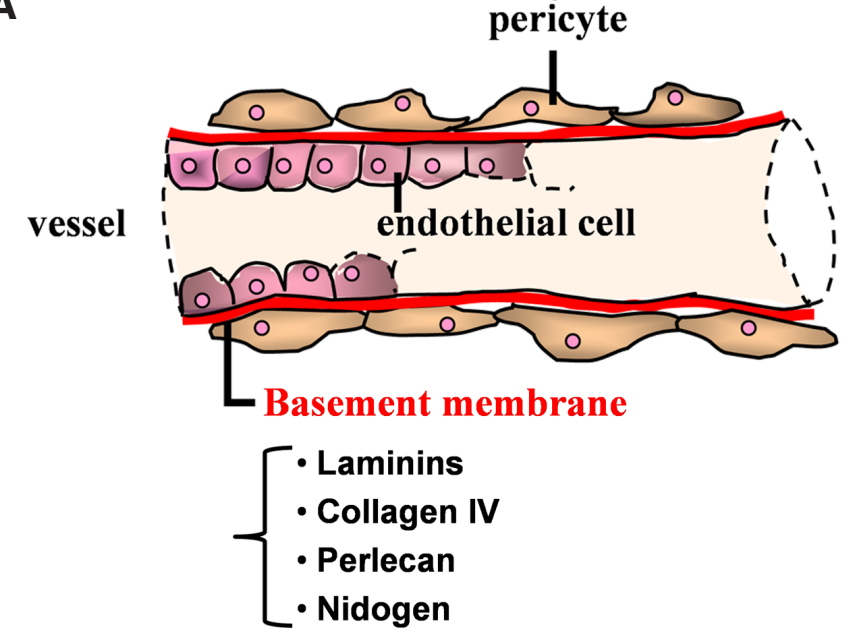

B

\section{Laminin isoforms}

\begin{tabular}{|c|c|}
\hline Name & Chain composition \\
\hline Laminin-111 & $\alpha 1 \beta 1 \gamma 1$ \\
\hline Laminin-121 & $\alpha 1 \beta 2 \gamma 1$ \\
\hline Laminin-211 & $\alpha 2 \beta 1 \gamma 1$ \\
\hline Laminin-213 & $\alpha 2 \beta 1 \gamma 3$ \\
\hline Laminin-221 & $\alpha 2 \beta 2 \gamma 1$ \\
\hline Laminin-311 & $\alpha 3 \beta 1 \gamma 1$ \\
\hline Laminin-321 & $\alpha 3 \beta 2 \gamma 1$ \\
\hline Laminin-332 & $\alpha 3 \beta 3 \gamma 2$ \\
\hline Laminin-411 & $\alpha 4 \beta 1 \gamma 1$ \\
\hline Laminin-421 & $\alpha 4 \beta 2 \gamma 1$ \\
\hline Laminin-423 & $\alpha 4 \beta 2 \gamma 3$ \\
\hline Laminin-511 & $\alpha 5 \beta 1 \gamma 1$ \\
\hline Laminin-521 & $\alpha 5 \beta 2 \gamma 1$ \\
\hline Laminin-522 & $\alpha 5 \beta 2 \gamma 2$ \\
\hline Laminin-523 & $\alpha 5 \beta 2 \gamma 3$ \\
\hline
\end{tabular}

Fig. 1. The basement membrane constituents in vessels and presentation of the laminin family. (A) In a quiescent capillary a BM separates endothelial cells from supporting cells such as pericytes and the connective tissue. The BM is composed of 4 major types of molecules: $L M$, collagen type IV, perlecan and nidogen. (B) The 15 different $L M$ isoforms are composed of $\alpha, \beta$ and $\gamma$ chains forming hetrotrimers. Name and chain composition are presented. 


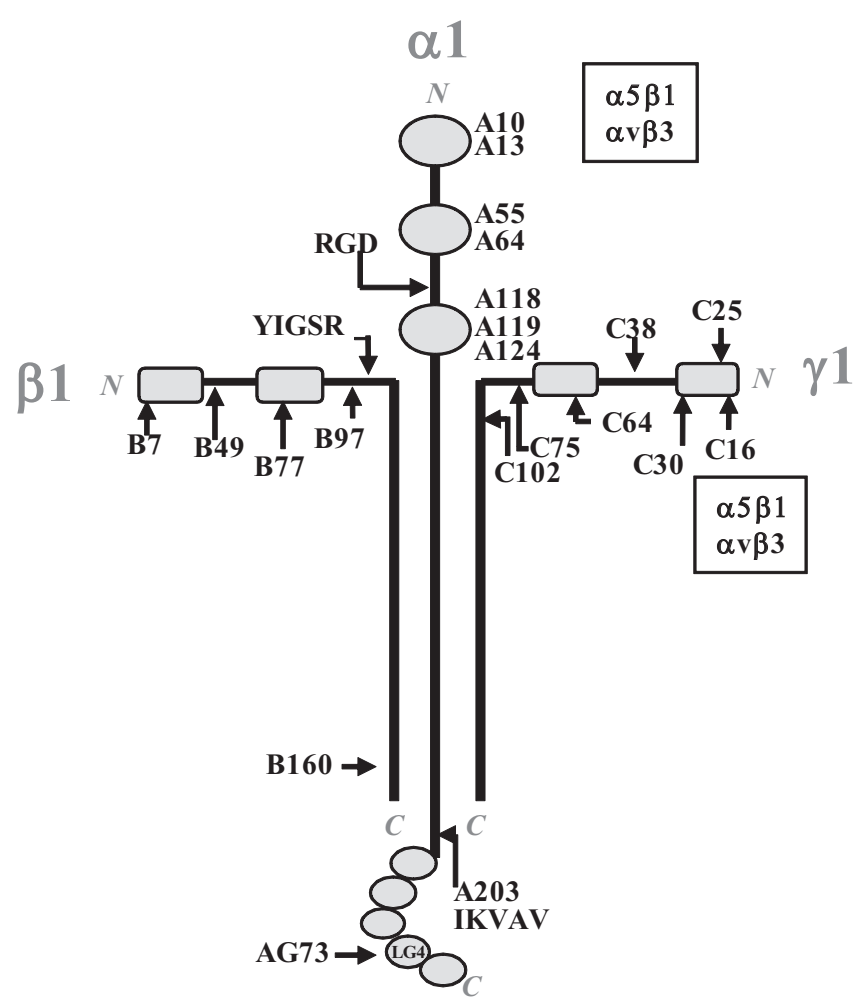

Fig. 2. Schematic model of the LM-111 molecule ( $\alpha 1 \beta 1 \gamma 1)$ and its peptide domains active on endothelial cells (EC). The location of LM-111 synthetic peptides that act on angiogenesis is indicated by arrows. Most of the identified peptides located on the $\alpha, \beta$ or $\gamma$ arm of LM (designated respectively by $A, B$ or $C$ letters) are positively regulating $E C$ behaviour. Peptide YIGSR located on the $\alpha 1$ chain inhibits angiogenesis. Peptides A13 or $C 16$ bind to integrin $\alpha 5 \beta 1$ and $\alpha v \beta 3$ receptors whereas intact $L M-111$ does not bind to these integrins. Note that B7 peptide is located within the putative signal sequence of the $\beta 1$ chain. Globular domains of LM-111 are represented in grey. $N$, amino terminus domain; $C$, carboxy terminus domain; LG4, LM C-terminal G domain (module 4).

and Matrigel into nude mice. Under this condition, the peptide enhanced tumour vascularisation as well as tumour growth over that observed with melanoma cells or Matrigel alone (Kibbey et al., 1992). In order to identify additional active sites within the LM molecule, a screen was performed on 405 synthetic partially overlapping peptides that were derived from the $\alpha 1$ chain (Nomizu et al. 1995; Malinda et al., 1999). Using the HUVEC tube formation and $E C$ rat aortic ring sprouting assay, eight peptides A10, A13, A55, A64, A118, A119, A124 and A203 were found to be active in angiogenesis (Fig. 2). Of interest is the fact that the $\alpha 1$ chain peptides are predominantly clustered in the first, second and third globular domain (Malinda et al., 1999). The A13 peptide (RQVFQVAYIIIKA), which was the most active in the angiogenesis assays, also promoted melanoma lung colonization (Kuratomi et al., 1999).

The synthetic peptide AG73 derived from the LM $\alpha 1$ chain carboxy-terminal globular domain (G domain, LG4 module) (Fig. 2) turned out to be a very potent stimulator of angiogenesis (Mochizuki et al., 2007). Again, this peptide promoted angiogenesis in the aortic ring and in the CAM assays. Interestingly, peptides with homologous sequences in $\operatorname{LM} \alpha 2, \alpha 3, \alpha 4$ or $\alpha 5$ chain were not as angiogenic as was AG73 (Mochizuki et al., 2007) which suggests a particular role of the intact as well as the proteolysed LM $\alpha 1$ chain in angiogenesis.

In accordance with this pro-angiogenic effect of the $L M \alpha 1$ chain, its overexpression by transfection in human colon adenocarcinoma cells increased angiogenesis and growth of the arising tumours and promoted recruitment of stromal cells (De Arcangelis et al., 2001; Fig. 3 panel I). In contrast, mutated versions of Lama1 in zebrafish morphants delayed or reduced EC differentiation, formation of capillaries as well as blood flow in the hyaloid vasculature (Semina et al., 2006). In mice with a recessive mutant Lama1 gene that was generated by chemical mutagenesis, EC development was also delayed. A more severe phenotype was observed in a Lama1 null mouse mutant that derived from Sox2-cre induced deletion of the floxed Lama1 gene (Fig. 3 panel II). These mice were blind and exhibited tortuous vessels with persistence of hyaloid vessels in the retina (Edwards et al., 2010). This observation points at a crucial role of the LM $\alpha 1$ chain in proper retinal blood vessel development.

\section{Pro- and anti-angiogenic properties located within the laminin $\beta 1$ chain}

As for the $\alpha 1$ chain, short synthetic peptides from the $\beta 1$ chain of LM were screened for their potential effect on EC adhesion in Matrigel, the aortic ring and the Boyden chamber assays (Nomizu et al.1995; Malinda et al., 1999). Five peptides of the $\beta 1$ chain, B49, $\mathrm{B} 77, \mathrm{~B} 97, \mathrm{~B} 160$ and B7, were found to be active in angiogenesis (Fig. 2). Yet, another sequence (YIGSR) located in the $\beta 1$ chain had an opposite biological activity since it inhibited angiogenesis (Fig. 2). Kubota et al., (1988) and Grant et al., (1989) found that a peptide containing the YIGSR sequence blocked the morphological differentiation of EC into capillary-like structures. This peptide also inhibited embryonic angiogenesis in the CAM assay (Sakamoto et al., 1991). Of interest is the fact that this peptide also inhibited experimental metastasis formation of melanoma cells (Iwamoto et al., 1987) suggesting that this peptide may not only block angiogenesis but also other steps during metastasis. Thus this peptide may potentially find application in cancer therapy.

\section{Activation of signalling pathways in response to cell interactions with laminin-111}

\section{Binding of angiogenic peptides of the laminin $\alpha 1$ and $\gamma 1$ chains to $\alpha v \beta 3$ and $\alpha 5 \beta 1$ integrins}

To search for angiogenic sequences 154 overlapping synthetic peptides were generated that span the entire LM $\gamma 1$ chain (Ponce et al., 1999). The authors identified 7 peptides (C16, C25, C30, $\mathrm{C} 38, \mathrm{C} 64, \mathrm{C} 75$ and C102) that inhibited Matrigel-induced formation of capillary-like structures of EC by competition. Moreover, these peptides promoted angiogenesis in the aortic ring assay and in the CAM assay (Fig. 2). The most active peptide C16 (KAFDITYVRLK) bound to integrins $\alpha \mathrm{v} \beta 3$ and $\alpha 5 \beta 1$ (Ponce et al., 2001). Unexpectedly, the angiogenic peptide A13 located in the $\mathrm{N}$-terminal globular domain of the LM $\alpha 1$ chain represented a redundant active site found in the $\mathrm{C} 16$ peptide (Ponce and Kleinman, 2003). Both peptides A13 and C16 bound to the same integrin and competed with each other in cell adhesion and angiogenesis. Binding of these peptides to integrins $\alpha v \beta 3$ and $\alpha 5 \beta 1$ was rather surprising since these integrins are not classical LM receptors 
(Avraamides et al., 2008; Silva et al., 2008). Since intact LM do not bind to these integrins it is likely that the A13 and C16 sequences represent crytic sites. Whether and how they are released from the intact molecule is not known. Although A13 and $\mathrm{C} 16$ bound to integrins, they did not induce classical integrin signalling such as activation of mitogen-activated protein kinase or serine/threonine kinases (Ponce et al., 2001). There is nothing known about what signalling is induced upon ligation of the integrins by these laminin peptides. It is intriguing that the $\mathrm{A} 13$ or $\mathrm{C} 16$ sequences are found in almost all LM isoforms: A13 in LM-111 and LM-121, and C16 in 11 out of the 15 isoforms. This high conservation may indicate the importance of this sequence for development and angiogenesis.

In cancer, a peculiar mechanism of tumour cell dissemination was described where tumour cells migrated along the external surface of vessels; this mechanism is called extravascular migratory metastasis (Lugassy and Barnhill, 2007). In the CAM assay, the C16 peptide was shown to increase extravascular migration of human GFP labelled melanoma cells along vessels although it was not addressed whether it affected angiogenesis (Lugassy et al., 2009). Because of the putative significance of this LM $\gamma 1$ sequence in modulating angiogenesis, Ponce et al.,2003) had searched for a more potent peptide and discovered $\mathrm{C} 16 \mathrm{Y}$ which was five times more active. Intraperitoneal injections of this peptide also inhibited angiogenesis and growth of xenografted breast cancer cells in mice. The minimal active sequence of $\mathrm{C} 16 \mathrm{Y}$ was identified as DFKLFAVY and presumably functions as an antagonist for integrins $\alpha v \beta 3$ and $\alpha 5 \beta 1$ during angiogenesis. Since these integrins are a target in cancer therapy the described LM sequences blocking these integrins have a potential for drug development.

\section{A cryptic RGD domain in the laminin $\alpha 1$ chain}

Binding of various integrins to extracellular ligands is a major initial event in cell-matrix interactions. EC and pericytes express a large subset of integrins that include typical LM receptors such as $\alpha 2 \beta 1, \alpha 3 \beta 1, \alpha 6 \beta 1, \alpha 6 \beta 4, \alpha 7 \beta 1$ (Avraamides et al., 2008; Silva et al., 2008). Interestingly, the repertoire of integrins on EC changes during angiogenesis (Silva et al., 2008). Among these are integrins that recognize the well-known cell-adhesive RGD (Arg-Gly-Asp) site in matrix molecules. Yet, RGD sequences are rarely found in laminins. In the mouse $\alpha 1$ chain, a cryptic RGD site was identified and was located in the fragment P1 upon pepsin digestion (Aumailley et al., 1991). Although some conflicting results exist in the literature regarding the implication of this RGD site in regulating cell adhesion of EC to LM, it was shown that the differentiation of EC into tube-like structures required an initial integrin-dependent attachment to an RGD-containing sequence present in LM $\alpha 1$. This initial integrin-mediated interaction was followed by a cell-cell interaction through the YIGSR sequence on the LM $\beta 1$ chain (Grant et al., 1989; Aumailley et al., 1991). Thus proteolytic release of the RGD sequence from the $\alpha 1$ chain was necessary for cell adhesion. This raises the question about the role of this mechanism in normal tissue where proteolytic activity is low. Yet, this mechanism might be relevant in inflammatory and tumourigenic tissues that exhibit a high proteolytic activity.

\section{Signalling events triggered by cell adhesion to laminin-111}

It is not yet clear how small peptides or the entire LM-111 molecule exhibit a biological response. In the CAM assay, Dixelius et al., (2004) demonstrated that intact LM-111 was as potent as FGF-2
I. Overexpression of laminin $\alpha 1$

Fig. 3. Documentation of the proangiogenic properties of the LM $\alpha 1$ chain. (Panel I) Ectopic expression of $L M \alpha 1$ under control of the cytomegalovirus promoter in HT29 colorectal carcinoma cells that do not express endogenously $L M \alpha 1$ in cell culture. Overexpression of $L M \alpha 1$ caused an increased tumour growth $\mathbf{( A ; C}$ versus B), a strong recruitment of fibroblasts (Masson's Trichrome staining), (E,D) and enhanced angiogenesis (immunostaining for CD31) (G,F) upon xenografting under the skin of nude mice (De Arcangelis et al., 2001). (Panel II) The absence of $L M \alpha 1$ in knockout mice interfered with normal blood vessel development in the retina (Edwards et al., 2010). Retinas from postnatal day $7 L M \alpha 1$ knockout mice (B) exhibited a poor primary retinal plexus in contrast to wildtype mice that showed an organised vasculature with capillaries and small branched vessels (A) as visualised with Griffonia simplicifolia isolectin staining. Abnormal blood vessel organisation is still obvious in the adult stage as visualised by staining for ADPase showing tortuous capillaries and larger vessels extending into the vitreous (D,C).
A
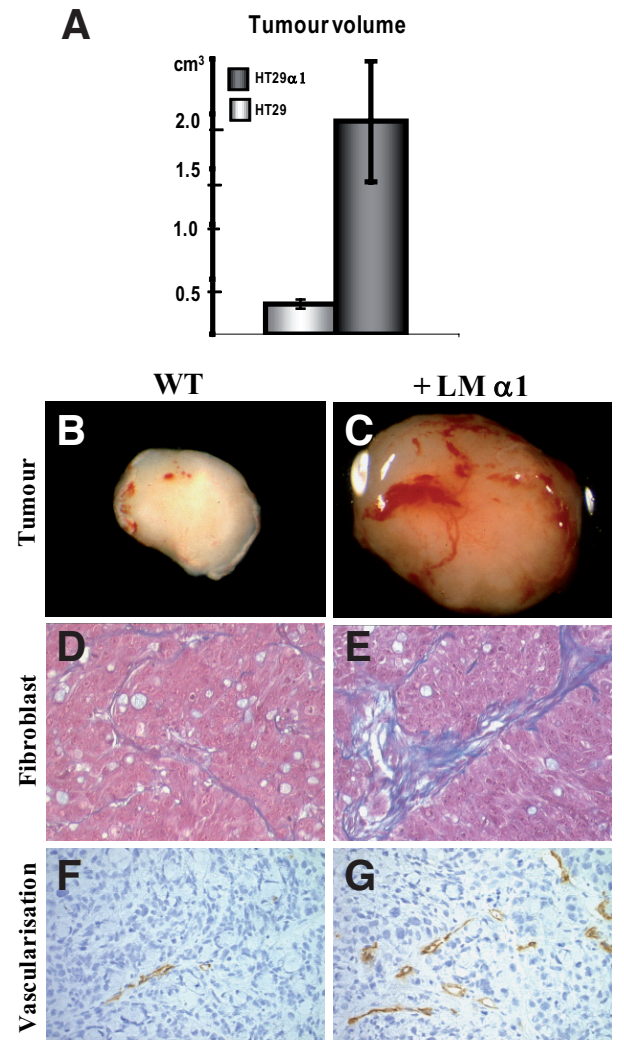

G

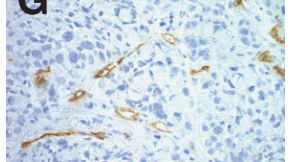

\section{Ablation of laminin $\alpha 1$}
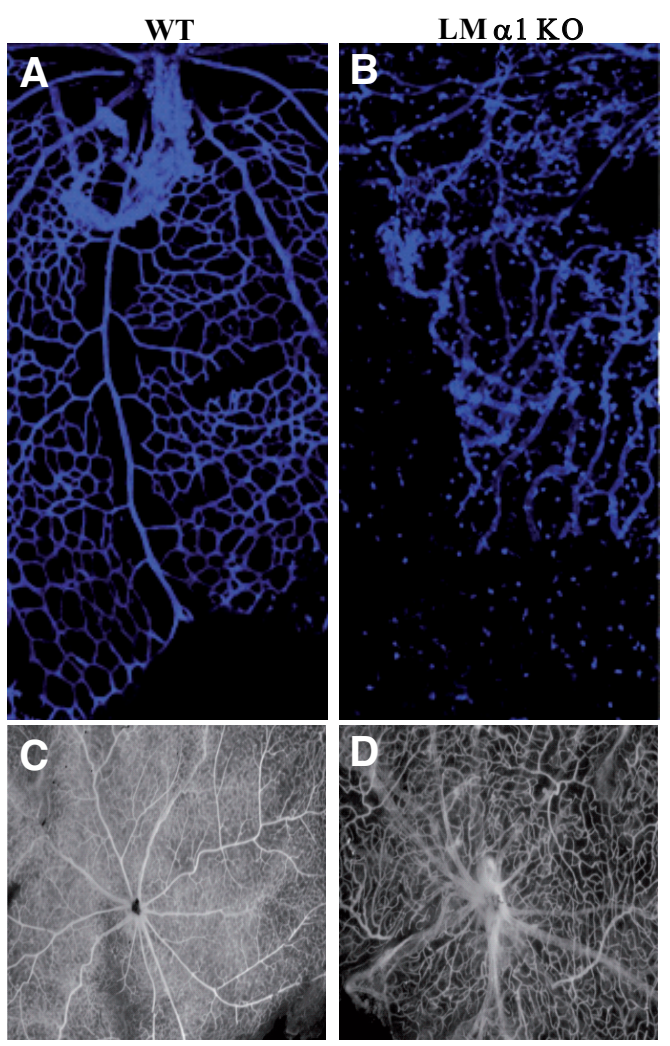
to induce angiogenesis, that vascular development in embryoid bodies was stimulated in a synergistic manner by FGF-2 together with LM-111, and that formation of tubular structures was accompanied by increased expression of Jagged-1, a ligand of the Notch receptor family and a marker of endothelial differentiation. They further showed that the combined presence of LM-111 and FGF2 led to a transient increase of FGFR-1, VEGF-A and VEGFR-2 mRNA levels. Yet, LM-111 failed to activate classical angiogenic growth factor-induced signalling such as phospho-ERK-1/-2 or phospho-Akt. Cell attachment to LM is mediated by cell adhesion receptors such as integrins, syndecans, dystroglycan and Lutheran (Durbeej, 2010). Although studies were not done with EC, one can assume that the pro-angiogenic $A 13$ peptide of the $\alpha 1$ chain likely binds to an integrin containing the $\beta 1$ subunit since an interaction of A13 with a $\beta 1$ integrin was found in HT-1080 human fibrosarcoma cells and hepatocytes (Nomizu et al., 1998; Kikkawa et al., 2009). Moreover, the angiogenic AG73 peptide also found in the $\alpha 1$ chain, was shown to interact with members of the transmembrane syndecan family of proteoglycans, syndecan-1 and presumably syndecan-4 (Hoffman et al., 1998; Mochizuki et al., 2007) that are critical regulators of angiogenesis.

\section{Potential role of proteolytic processing of laminin in angio- genesis}

Except a role of Notch and VEGF signalling (Jakobsson et al., 2009), little is known how EC are stimulated to form a branch from a parental vessel. The BM itself or BM associated factors and enzymes might play a decisive role in branching of capillaries. Matrix remodelling is a key step in vessel branching and LM-111 might play a role in this process. In particular, the IKVAV-containing peptide in the $\alpha 1$ chain was shown to promote endothelial collagenase IV activity (Grant et al., 1992; Schnaper et al., 1993). This peptide also increased plasminogen activation, resulting in the degradation of LM, as well as of matrix metalloproteinase MMP9 in melanoma cells and macrophages (Stack et al., 1993; Faisal Khan and Falcone, 1997). An increased protease activity could also trigger release of matrix bound growth factors such as VEGF, FGF, PDGF and thus the action of IKVAV would be rather indirect. In contrast to the IKVAV peptide, all other angiogenic peptides derived from the globular domains of the LM $\alpha 1$ chain, including the $\mathrm{A} 13$ sequence, did not stimulate MMP activity in a zymogram assay (Malinda et al., 1999).

\section{Summary}

Several sequences within the LM $\alpha 1-, \beta 1$-and $\gamma 1$ chains regulate angiogenesis. Some of them such as the RGD and IKVAV sites are presumably cryptic in the intact LM-111 molecule and need to be unmasked by proteases to be active. These sequences promote early steps in angiogenesis such as cell migration, formation of differentiated spindle-shaped cells, production of proteases, loss of contact inhibition, and expression of matrix molecules that facilitate cell attachment to the ECM (Grant et al., 1994). Another class of pro-angiogenic peptides located in the $\mathrm{N}$-terminal domain of the LM $\alpha 1$ chain, such as the A13 peptide, is also active in context of the intact molecule and may be accessible upon a conformational change. The reason for the large number of pro-angiogenic peptides in LM-111 is not clear. Depending on the surrounding microenvironment and proteolytic activities, alternative peptides may be generated from the $L M \alpha 1$ chain which may modulate angiogenesis by different mechanisms. Finally, synthetic peptides of LM-111 could be used to improve our understanding of the biological functions of this laminin in angiogenesis and may provide the basis for drug development to regulate angiogenesis in pathological situations.

\section{The laminin $\alpha 4$ chain regulates endothelial cell behaviour and angiogenesis}

The $L M \alpha 4$ chain is a component of two laminins, LM- $411(\alpha 4 \beta 1 \gamma 1)$ and LM-421 ( $\alpha 4 \beta 2 \gamma 1)$ and is widely distributed invascular endothelial BMs of several tissues. Since the $\beta 2, \beta 3, \gamma 2$ and $\gamma 3$ chains have not been found in capillaries, LM-411 is presumably the only LM trimer in the capillary BMs of most embryonic and neonatal tissues (Hallmann et al., 2005). The widespread and exclusive expression of the $\alpha 4$ chain in BM of developing microvessels suggests a role in angiogenic processes. Indeed, it was shown that the LM $\alpha 4$ subunit has a strong impact on EC behaviour (Gonzales et al., 2001; Gonzalez et al., 2002). In addition it was demonstrated that the $\mathrm{G}$ domain of LM $\alpha 4$ is a specific high affinity ligand for $\alpha \mathrm{v} \beta 3$ and $\alpha 3 \beta 1$ integrins. These two integrins together with the $\alpha 6 \beta 1$ integrin cooperatively mediate EC interactions with $\alpha 4$ containing LM by promoting cell adhesion and migration (Gonzalez et al., 2002). Similarly, the overexpression of the LM $\alpha 4$ chain in human dermal microvascular EC promoted cell spreading and migration in a scratch wound assay and accelerated angiogenic tube formation in collagen gel overlay assays (Li et al., 2006). By using a panel of dominant-negative mutants of Rho family GTPases, Fujiwara et al., (2004) showed the importance of Rac activation in $\alpha 6 \beta 1$ integrin-mediated EC adhesion and migration on LM-411. Other in vitro studies suggested that the $\alpha 4$ LM chain can directly regulate cell proliferation and inhibit apoptosis. In particular an antibody directed against the $\mathrm{G}$ domain was able to trigger a mitochondrial-dependent programmed cell death pathway in EC (DeHahn et al., 2004) which suggests that cell binding to the LM $\alpha 4$ chain is essential for survival. The authors further showed that the anti-apoptotic signal emanating from the interaction with the $\alpha 4$ LM chain was transduced via integrin $\alpha 3 \beta 1$ and/or $\alpha 6 \beta 1$.

Studies of $L M-\alpha 4$ deficient mice revealed that this chain is not required for blood vessel formation; yet, Lama4 knock-out mice displayed certain vascular abnormalities. In particular they exhibited an unstable and weakened capillary BM. Rupturing of the microvascular wall led to mild transient haemorrhages in the skin of newborn mice. Within the first week after birth, however, the vascular phenotype of Lama4 deficient mice disappeared most likely due to compensation by LM-511 which was largely deposited under these conditions (Thyboll et al., 2002). In adult Lama4 null corneas, the formation of new blood vessels was dramatically affected. In response to FGF-2 an extensive bleeding and disorganisation of the microvessel growth was observed in Lama4 deficient corneas (Thyboll et al., 2002; Zhou et al., 2004). In contrast to most microvessels where the $\alpha 4$ chain is produced by EC, in the kidney LM $\alpha 4$ is expressed by specialized pericytes, the mesangial cells. In Lama4 null mice the lack of the LM $\alpha 4$ chain caused a progressive renal lesion which was presumably due to deregulated PDGF-R $\beta$ signalling. In consequence pericyte recruitment and vessel lining was reduced (Abrass et al., 2010).

Comparing the expression between normal brain tissue and gliomas using a gene array approach combined with qRT-PCR and immunohistochemical staining revealed that the Lama4 gene was 
consistently overexpressed in the tumorigenic blood vessels as opposed to low levels found in normal brain tissue (Ljubimova et al., 2001). Moreover, in gliomas, LM-411 potentially plays a role in tumour regrowth since a high LM-411 expression correlated with a more rapid recurrence, but the underlying mechanism is unknown. Data suggest that during tumour progression a switch from $\beta 2$ containing LM to LM with a $\beta 1$ chain occurs. Indeed, normal blood vessels of brain and breast tissue expressed LM-421 which was in contrast to vessels in high grade gliomas and breast carcinoma that expressed LM-411 (Fujita et al., 2005; Ljubimova et al., 2006).

Yet, opposing data on the role of $\mathrm{LM} \alpha 4$ on tumour angiogenesis were obtained by Zhou et al., (2004). To determine the role of LM-411 in tumour growth and angiogenesis, they xenografted lung carcinoma cells under the skin of a Lama4 knockout mouse. Under these conditions the absence of host LM $\alpha 4$ accelerated tumour growth in comparison to control mice expressing the Lama4 gene. This was accompanied by an increased tumour vascularisation in the Lama4 knockout mice. These surprising data could be due to compensation by other LM such as $\alpha 5$ or $\alpha 1$ which may be induced in the absence of LM $\alpha 4$. An expression analysis of other $\alpha$ chains in tumours of Lama4 knockout mice may clarify this issue.

\section{Potential role of laminin $\alpha 5$ during angiogenesis}

LM $\alpha 5$ expression is developmentally regulated in vessels. In the mouse embryo, the $\alpha 5$ chain is only detected in large vessels; its expression in capillaries becomes evident only at 3-4 weeks after birth (Sorokin et al., 1997). Data on the influence of $\alpha 5$-containing LM on angiogenesis are still fragmentary and not conclusive. Targeted inactivation of the Lama5 gene encoding the LM $\alpha 5$ chain resulted in disturbed placental vessel development (Miner et al., 1998). As the Lama5 knockout embryo died at day 17, no data on later stages are available. But in the very early Lama5 knockout embryo it appears that the lack of this LM chain affects vessel stability and / or maturation (Miner, 2008). Using recombinant human LM-511 as substratum, Doi et al., (2002) showed that human vein EC adhered and migrated on this LM molecule in an integrin $\alpha 2 \beta 1$ and $\alpha 3 \beta 1$-mediated manner. Quantitative cell adhesion assays revealed that cells bound to LM-511 upon ligation of $\beta 1$ and $\alpha v \beta 3$ integrins which acted in concert with Lutheran, another $\alpha 5$ specific transmembrane adhesion receptor (Vainionpää et al., 2006). Yet, $\alpha 5$-containing LM seems to be unable to stimulate angiogenesis in the embryoid body model when ES cells were cultured together with purified LM. This is in contrast to LM-111 that had strongly induced angiogenesis (Dixelius et al., 2004).

It is possible that there is a balance between LM $\alpha 4$ and $L M \alpha 5$ chains since both are expressed in blood vessels. In the Lama4 knockout situation, compensation by the $\alpha 5$ chain presumably rendered mice viable. In contrast, Lama5 knockout mice are embryonic lethal despite local compensation in certain organs by other LM (Miner et al., 1998; Bolcato-Bellemin et al., 2003). No data are available regarding the vessel BM composition in the Lama5 mutants. In Lama4 knockout mice an increased expression of LM $\alpha 5$ was found that presumably stabilized the vessels. But these vessels were far from normal since they were dilated and fragile which may explain why mice developed cardiomyopathy with increased age (Thyboll et al., 2002; Wang et al., 2006b). A well controlled balance between LM $\alpha 4$ and LM $\alpha 5$ chain expression in the endothelial BM was demonstrated in an experimental autoimmune encephalomyelitis model (Wu et al., 2009). The authors showed that focal extravasation of leukocytes via integrin $\alpha 6 \beta 1$ was due to the patchy distribution of LM $\alpha 5$ in the BM. Transmigration of leukocytes occurred preferentially at sites that expressed high $\alpha 4$ containing LM but low amounts of $\alpha 5$ LM showing for the first time an instructive role of endothelial BM on T lymphocyte migration.

To identify adhesive sequences within LM $\alpha 5,113$ overlapping synthetic peptides of the globular domains had been tested in cell attachment assays (Hibino et al., 2004). Four peptides (A5G27, A5G73, A5G81, A5G101) were found to inhibit FGF-induced angiogenesis in the CAM assay. One of these peptides, A5G27, was able to bind the CD44 receptor that is present on EC and inhibited angiogenesis in a dominant-negative manner. It is interesting to note that CD44 is expressed in the vasculature of tumours as a result of an exposure to angiogenic factors such as bFGF and VEGF (Griffioen et al., 1997). Whether this peptide is generated in vivo or whether the A5G27 sequence is binding to CD44 in context of the intact LM molecule is not known. This information would be useful for tumour angiogenesis intervention strategies.

\section{Laminin-332 in matrix channels and the vasculature}

LM-332, composed of an $\alpha 3, \beta 3$ and $\gamma 2$ subunit, is typically expressed in the BM of epithelial tissues such as skin, stomach, lung, breast and intestine. In stratified epithelia such as the skin, LM-332 is detected in type I hemidesmosomes, adhesion stuctures containing $\alpha 6 \beta 4$ integrin, cytokeratins and several hemidesmosomal proteins (de Pereda et al., 2009). Because LM-332 plays a key role in controlling migration of cells (Giannelli and Antonaci, 2001), it is possible that it plays a similar role in mesodermal tissues. The $\gamma 2$ chain, found in LM-332 and LM-522, is expressed in the intestinal smooth muscle coat (Orian-Rousseau et al., 1996) and at low levels in the tunica media of aorta and pulmonary arteries (Kingsley et al., 2002a). Interestingly these vascular smooth muscle cells responded to soluble growth factors such as PDGF and TGF- $\beta 1$ by increasing their endogenous levels of LM-332 while reducing adhesion to this substratum (Kingsley et al., 2002a). PDGF-BB enhanced cell migration of vascular smooth muscle cells on LM332 via an ERK1/2 signalling pathway (Kingsley et al., 2002b). The importance of the mesenchyme-derived cells in producing and secreting LM-332 is further supported by interspecies tissue recombination experiments using endodermal and mesenchymal anlagen of mouse and chicken, respectively. Species-specific antibodies were used to show that the LM $\gamma 2$ chain was deposited by the mesenchymal cells only (Orian-Rousseau et al., 1996). These data suggest that LM $\gamma 2$-containing LM might be important for mesodermal tissue identity.

The available literature regarding the function of LM-332 in vascular biology is limited. Ahesion of cells to LM-322 appears to promote migration through integrin $\alpha 3 \beta 1$ and to facilitate hemidesomosome formation through integrin $\alpha 6 \beta 4$ (Litjens et al., 2006). Kikkawa et al., (1996) showed that EC bound to this isoform (formerly called ladsin) via integrin $\alpha 3 \beta 1$ and this interaction increased cell migration. In contrast, Homan et al., (1998) demonstrated that a LM-332 rich matrix in concert with integrin $\alpha 6 \beta 4$ and vimentin promoted the assembly of stable hemidesmosome-like adhesion structures in EC. This knowledge is already applied in bioengineering of biomedical implants (Kidd and Williams, 2004; Kidd et al., 2005). It was shown that LM-332 enriched polytetrafluoroethylene 
(PTFE) scaffolds (a porous polymer that permits vessel ingrowth through the pores of the material) increased tissue vascularisation. More importantly, the authors had shown that LM-332 accelerated neovascularisation upon implantation of the PTFE scaffolds into the mouse (Kidd et al., 2005).

In highly aggressive melanomas, cells form a matrix network that appears to be connected to the vasculature and that has been coined "vasculogenic mimicry" (Maniotis et al., 1999) or tubular channel formation (Kaariainen et al., 2006). These conducting structures are rich in LM $\gamma 2$ containing laminins but are not lined by EC thus potentially recapitulating embryonic vasculogenesis (Hendrix et al., 2003). These channels may play a role in transporting plasma and blood and potentially serve as short distance route for tumour cells (Kaariainen et al., 2006). Interestingly, a high level of similarity between the vasculogenic mimicry of tumours and the ancestral vascular tube formation -found in the invertebrate blood vesselswas noted (Kucera et al., 2009). Similar to the invertebrate blood vessels, LM-containing ECM lined these vessels within the tumour. Upregulation of the lamc2 gene (encoding the $\gamma 2$ chain) and of other genes implicated in angiogenesis and vasculogenesis such as cadherin 15, ephrin receptor A2 and several MMPs was found in aggressive melanoma cells (Seftor et al., 2001; Hendrix et al., 2003). An important role of $\gamma 2$ LM in tube formation was demonstrated upon reducing expression of this isoform by an antisense oligonucleotide knockout strategy in aggressive melanoma cells. Downregulation of the LM $\gamma 2$ chain resulted in the inability to form vasculogenic-like networks in 3D-cultures (Seftor et al., 2001). A similar matrix-based tube formation had been described in various carcinomas (Hendrix et al., 2003; Kucera and Lammert, 2009). The potential role of LM $\gamma 2$ in tumour angiogenesis is unknown. It is interesting to note that cathepsin $S$ cleaved the $\gamma 2$ chain giving rise to pro-migratory fragments (Giannelli and Antonaci, 2001). Deficiency of cathepsin S in the RIP1-Tag2 model of pancreatic islet carcinogenesis impaired angiogenesis (Wang et al., 2006a).

\section{Role of laminin during basement membrane assembly in angiogenesis}

An important step in angiogenesis is the formation of an endothelial lumen giving rise to a tube. On their basal surface EC are first in contact with the BM which maintain the tube structure. This BM and in particular LM appear to be instrumental in forming capillary-like structures (Kubota et al., 1988) by potentially serving as guiding cue for pericytes that will extend cellular processes to contacting EC (von Tell et al., 2006). The recruitment of pericytes to EC-lined tubes will stabilize the vessels and lead to neosynthesis and assembly of BM molecules (Davis et al., 2007) which had been nicely demonstrated in a coculture assay (Stratman et al., 2009). By using species-specific primers in heterospecific cocultures (human EC with bovine pericytes) it was shown that certain LM chains were induced which did not occur if each cell type was cultured alone (Stratman et al., 2009). In particular the $\alpha 4, \alpha 5, \beta 2$ and $\gamma 1$ chains were induced in the coculture setting which points at a possible role of the associated LM, most importantly LM-511 and LM-521 in vascular BM assembly (Miner and Yurchenco, 2004). Coincident with these events, upregulation of integrins $\alpha 5 \beta 1, \alpha 3 \beta 1, \alpha 6 \beta 1$ and $\alpha 1 \beta 1$ occurred in EC-pericyte cocultures that may strengthen the physical interaction between cells and their substratum (Stratman et al., 2009). These findings confirm the essential role of hetero- typic cell-cell interactions in controlling BM matrix assembly, a phenomenon not restricted to the vascular BM (Simon-Assmann et al., 2010). These data also emphasise the active participation of pericytes in vessel stabilisation since they are able to produce multiple LM isoforms and type IV collagen (Jeon et al., 1996). The tight interaction between pericytes and EC is presumably further stabilized by cell-cell contacts through integrins and the vascular cell adhesion molecule 1 (Desgrosselier and Cheresh, 2010). Importantly, abnormal interactions of pericytes with EC or the complete lack of pericytes play a role in the pathogenesis of some diseases such as cancer and diabetes (Davis et al., 2007; Huang et al., 2010).

Another example of an important role of BM molecules in the vasculature had been described in the endocrine pancreas (Nikolova et al., 2006). The authors showed that EC provided pancreatic $\beta$ cells with a vascular BM which was essential for proliferation and insulin secretion. First, $\beta$-cells secreted VEGF-A which attracted $\mathrm{EC}$ and triggered formation of a LM-rich BM coat around the capillaries. Subsequently, integrin mediated $\beta$-cell interactions with LM promoted insulin expression and $\beta$-cell proliferation. In summary it appears that a coordinated binding of cells to LM and other BM components serves as prerequisite for a stable interaction between $\mathrm{EC}$ and pericytes that would allow vessel maturation as well as insulin secretion of the endocrine pancreas.

\section{Conclusion and future perspectives}

Angiogenesis is a complex process that involves many participants. Amongst them the LM within the BM not only provide a structural basis but also trigger cellular signalling, thus supporting or inhibiting vessel formation. These opposing effects of LM on angiogenesis do reside in their structural configuration that differs if LM are linked to other BM molecules or to cell adhesion receptors. Also cell responses are different if the LM are present as intact molecules or as peptides. The use of recombinant LM proteins or peptides allowed to decipher cell binding sites on individual LM chains. This approach did not take into account glycosylation and the native folding found in the entire molecule, and thus might have missed some interactions. Nevertheless, the fact that some of these sequences were cryptic points to the notion that proteolysis within the tissue is important to generate active or inactive sites. Proteolytic processing of LM appears to be particularly important in tumour angiogenesis.

Since BM are critically involved in blood vessel formation in normal and pathological tissue homeostasis their components are currently an area of intensive research for identification of novel anti-cancer therapies and controlled angiogenesis in tissue repair. One difficulty to encounter is that vascular BMs in distinct tissues and organs exhibit different compositions. In contrast to most organs that express LM-411 and LM-511, blood vessels in the central nervous system express LM-111 and LM-211 (Ljubimova et al., 2001). Under pathological conditions such as in tumour vessels other LM isoforms are expressed than in normal tissue. In particular $\alpha 2, \alpha 3$ and $\beta 2$ containing LM are frequently found in tumour microvessels while they are usually not expressed in healthy tissues (Patarroyo et al., 2002). In addition to LM, also other molecules of the BM are critically involved in regulating vessel homeostasis. Type IV collagen is one such molecule that directly interacts with LM which may affect cell responses to LM. Moreover, in contrast to full length type IV 
collagen that supports and promotes angiogenesis, peptides of the $\mathrm{N}$-terminal domain of collagen type IV, known as arrestin, canstatin and tumstatin, are potent inhibitors of angiogenesis (Kalluri, 2003). Similar ambiguous properties, supporting angiogenesis as intact molecule but inhibiting angiogenesis when presented as peptides may also apply to LM. Yet, the underlying mechanisms need to be investigated in more detail.

In the future, a combination of complete or conditional deletion of LM-subunit genes in EC and pericytes will further improve our understanding of the particular function of LM in developmental and pathological angiogenesis. In this respect transgenic mice expressing Cre recombinase by cell type specific promoters such as the EC specific Tie-1, Tie-2, VE-cadherin promoters or the pericyte specific PDGF-R $\beta$ promoter will be useful to remove floxed LM genes.

Finally, the knowledge about the function of LM in the BM of the vasculature can also be used for tissue engineering and tissue repair. Cells derived from host organs are hampered to assemble into a functional tissue without a proper scaffold of a BM and connective tissue. In mice Matrigel presents a scaffold that supports growth of grafted cells (Kleinman and Martin, 2005). But for tissue engineering in humans the mouse-derived Matrigel cannot be used since it would raise an antigenic response. Therefore artificial biomimetic matrices have to be designed to support BM assembly and cell attachment that would provide signals for cell growth and differentiation (Lutolf and Hubbell, 2005). One step in direction of tissue engineering had been done by Nakamura et al., (2008 and 2009). The authors had developped biomimetic supports with collagen-binding activities that promoted the formation of a vascular network to provide artificial tissue substitutes as an alternative for donor tissue and organs.

\section{Acknowledgments}

The recent author's work has been supported by Inserm and grants from INCa (Institut National contre le Cancer) and ARC (Association pour la recherche sur le Cancer) to PSA and GO. PSA and OL were supported by grants from the Ligue Contre le Cancer. GO acknowledges support from University of Strasbourg and the CHU Strasbourg. CS and EM-B are recipients of grants from Ligue Contre le Cancer and the Atropatena Technological Equipment Company (Azerbaijan Republic), respectively. We also like to thank M. Kedinger for her constant support, C. Arnold and A. Klein for their skilful technical assistance throughout the years and Dr MM Edwards (Jackson Laboratory, Bar Harbor, Maine, USA) for sharing data concerning the angiogenic properties in retina.

\section{References}

ABRASS CK, HANSEN KM, PATTON BL (2010). Laminin alpha4-null mutant mice develop chronic kidney disease with persistent overexpression of platelet-derived growth factor. Am J Pathol 176: 839-849.

ALPY F, JIVKOV I, SOROKIN L, KLEIN A, ARNOLD C, HUSS Y, KEDINGER M, SIMON-ASSMANN P, LEFEBVRE O (2005). Generation of a conditionally null allele of the laminin alpha1 gene. Genesis 43: 59-70.

AUMAILLEY M, TIMPL R, RISAU W (1991). Differences in laminin fragment interactions of normal and transformed endothelial cells. Exp Cell Res 196: 177-183.

AVRAAMIDES CJ, GARMY-SUSINI B, VARNER JA (2008). Integrins in angiogenesis and lymphangiogenesis. Nat Rev Cancer 8: 604-617.

BARCZYK M, CARRACEDO S, GULLBERG D (2009). Integrins. Cell Tissue Res 339: 269-280

BOLCATO-BELLEMIN AL, LEFEBVRE O, ARNOLD C, SOROKIN L, MINER JH, KEDINGER M, SIMON-ASSMANN P (2003). Laminin alpha5 chain is required for intestinal smooth muscle development. Dev Biol 15:376-390.
CIMPEAN AM, RIBATTI D, RAICA M. (2011). A brief history of angiogenesis assays. Int J Dev Biol 55: 377-382.

DAVIS GE, KOHW, STRATMANAN (2007). Mechanisms controlling human endothelial lumen formation and tube assembly in three-dimensional extracellular matrices. Birth Defects Res C Embryo Today 81: 270-285.

DAVIS GE, SENGERDR (2005). Endothelial extracellular matrix: biosynthesis, remodeling, and functions during vascular morphogenesis and neovessel stabilization. Circ Res 97: 1093-1107.

DE ARCANGELIS A, LEFEBVRE O, MÉCHINE-NEUVILLE A, ARNOLD C, KLEIN A, RÉMY L, KEDINGER M, SIMON-ASSMANN P (2001). Overexpression of laminin $\alpha 1$ chain in colonic cancer cells induces an increase in tumor growth Int J Cancer 94: 44-53.

DE PEREDA JM, ORTEGA E, ALONSO-GARCIA N, GOMEZ-HERNANDEZ M, SONNENBERG A (2009). Advances and perspectives of the architecture of hemidesmosomes: lessons from structural biology. Cell Adh Migr 3: 361-364.

DEHAHN KC, GONZALES M, GONZALEZ AM, HOPKINSON SB, CHANDEL NS, BRUNELLE JK, JONES JCR (2004). The alpha4 laminin subunit regulates endothelial cell survival. Exp Cell Res 294: 281-289.

DESGROSELLIER JS, CHERESH DA (2010). Integrins in cancer: biological implications and therapeutic opportunities. Nat Rev Cancer 10: 9-22.

DIXELIUS J, JAKOBSSON L, GENERSCHE, BOHMAN S, EKBLOM P, CLAESSONWELSH L (2004). Laminin-1 promotes angiogenesis in synergy with fibroblast growth factor by distinct regulation of the gene and protein expression profile in endothelial cells. J Biol Chem 279: 23766-23772.

DOI M, THYBOLL J, KORTESMAA J, JANSSON K, IIVANAINEN A, PARVARDEH M TIMPL R, HEDIN U, SWEDENBORG J, TRYGGVASON K (2002). Recombinant human laminin-10 (alpha5beta1gamma1). Production, purification, and migrationpromoting activity on vascular endothelial cells. J Biol Chem 277: 12741-12748.

DURBEEJ M (2010). Laminins. Cell Tissue Res 339: 259-268.

EBLE JA, NILAND S (2009). The extracellular matrix of blood vessels. Current Pharmaceutical Design 15: 1385-1400.

EDWARDS MM, MAMMADOVA-BACH E, ALPY F, KLEIN A, HICKS WL, ROUX M SIMON-ASSMANN P, SMITH RS, OREND G, WU J, PEACHEY NS, NAGGERT JK, LEFEBVREO, NISHINAPM (2010). Mutations in Lama1 disrupt retinal vascular development and inner limiting membrane formation. JBiol Chem285: 7697-7711.

EKBLOM P, LONAI P, TALTS JF (2003). Expression and biological role of laminin-1. Matrix Biol 22: 35-47.

FAISAL KHAN MF, FALCONE DJ (1997). Role of laminin in matrix induction of macrophage urokinase-type plasminogen activator and 92-kDa metalloproteinase expression. J Biol Chem 272: 8270-8275.

FUJITA M, KHAZENZON N, BOSE S, SEKIGUCHI K, SASAKI T, CARTER W, LJUBIMOV A, BLACK K, LJUBIMOVA J (2005). Overexpression of beta1-chaincontaining laminins in capillary basement membranes of human breast cancer and its metastases. Breast Cancer Research 7: R411-R421.

FUJIWARAH, GU J, SEKIGUCHIK (2004). Rac regulates integrin-mediated endothelia cell adhesion and migration on laminin-8. Exp Cell Res 292: 67-77.

GARRIDO T, RIESE HH, ARACIL M, PEREZ-ARANDA A (1995). Endothelial cell differentiation into capillary-like structures in response to tumour cell conditioned medium: a modified chemotaxis chamber assay. Br J Cancer 71: 770-775.

GIANNELLI G, ANTONACI S (2001). Biological and clinical relevance of Laminin-5 in cancer. Clin Exp Metastasis 18: 439-443.

GONZALES M, WEKSLERD, TSURUTAD, GOLDMAN RD, YOON KJ, HOPKINSON SB, FLITNEY FW, JONES JCR (2001). Structure and function of a vimentinassociated matrix adhesion in endothelial cells. Mol Biol Cell 12:85-100.

GONZALEZAM, GONZALES M, HERRON GS, NAGAVARAPU U, HOPKINSON SB, TSURUTAD, JONES JCR (2002). Complex interactions between the laminin alpha 4 subunit and integrins regulate endothelial cell behavior in vitro and angiogenesis in vivo. Proc. Natl. Acad. Sci. USA 99: 16075-16080.

GRANT DS, TASHIRO K-I, SEGUI-REAL B, YAMADA Y, MARTIN GR, KLEINMAN HK (1989). Two different laminin domains mediate the differentiation of human endothelial cells into capillary-like structures in vitro. Cell 58: 933-943.

GRANT DS, KINSELLA JL, FRIDMAN R, AUERBACH R, PIASECKI BA, YAMADA Y ZAIN M, KLEINMAN HK (1992). Interaction of endothelial cells with a Laminin-A chain peptide (SIKVAV) in vitro and induction of angiogenic behavior in vivo. $J$ Cell Physiol 153: 614-625. 
GRANT DS, KIBBEY MC, KINSELLA JL, CID MC, KLEINMAN HK (1994). The role of basement membrane in angiogenesis and tumor growth. Pathol Res Pract 190: 854-863.

GRIFFIOEN AW, COENEN MJH, DAMEN CA, HELLWIG SMM, VAN WEERING HJ, VOOYS W, BLIJHAM GH, GROENEWEGEN G (1997). CD44 is involved in tumor angiogenesis; an activation antigen on human endothelial cells. Blood 90: 1150-1159.

GUSTAFSSON E, FÄSSLER R (2000). Insights into extracellular matrix functions from mutant mouse models. Exp Cell Res 261: 52-68.

HALLMANN R, HORN N, SELG M, WENDLER O, PAUSCH F, SOROKIN LM (2005). Expression and function of laminins in the embryonic and mature vasculature. Physiol Rev 85: 979-1000.

HENDRIX MJ, SEFTOR EA, HESS AR, SEFTOR RE (2003). Vasculogenic mimicry and tumour-cell plasticity: lessons from melanoma. Nat Rev Cancer 3: 411-421.

HIBINO S, SHIBUYA M, ENGBRING JA, MOCHIZUKI M, NOMIZU M, KLEINMAN HK (2004). Identification of an active site on the Laminin alpha5 chain globular domain that binds to CD44 and inhibits malignancy. Cancer Res 64: 4810-4816.

HOFFMAN MP, NOMIZU M, ROQUE E, LEE S, JUNG DW, YAMADA Y, KLEINMAN HK (1998). Laminin-1 and laminin-2 G-domain synthetic peptides bind syndecan-1 and are involved in acinar formation of a human submandibular gland cell line. $J$ Biol Chem 273: 28633-28641.

HOMANSM, MERCURIOAM, LAFLAMME SE (1998). Endothelial cells assemble two distinct $\alpha 6 \beta 4$-containing vimentin-associated structures: roles for ligand binding and the $\beta 4$ cytoplasmic tail. J Cell Sci 111: 2717-2728.

HUANG FJ, YOU WK, BONALDO P, SEYFRIED TN, PASQUALE EB, STALLCUP WB (2010). Pericyte deficiencies lead to aberrant tumor vascularizaton in the brain of the NG2 null mouse. Dev Biol 344: 1035-1046.

HUGHES CS, POSTOVIT LM, LAJOIE GA(2010). Matrigel: a complex protein mixture required for optimal growth of cell culture. Proteomics 10: 1886-1890.

INGBER DE (1992). Extracellular matrix as a solid-state regulator in angiogenesis: identification of new targets for anti-cancer therapy. Semin Cancer Bio/ 3: 57-63.

IWAMOTO Y, ROBEY FA, GRAF J, SASAKI M, KLEINMAN HK, YAMADA Y, MARTIN GR (1987). YIGSR, a synthetic laminin pentapeptide, inhibits experimental metastasis formation. Science 238: 1132-1134.

JAKOBSSON L, BENTLEY K, GERHARDTH (2009). VEGFRs and Notch: a dynamic collaboration in vascular patterning. Biochem Soc Trans 37,1233-1236.

JEON H, ONO M, KUMAGAI C, MIKI K, MORITAA, KITAGAWA Y (1996). Pericytes from microvessel fragment produce type IV collagen and multiple laminin isoforms. Biosci Biotechnol Biochem 60: 856-861.

KAARIAINEN E, NUMMELA P, SOIKKELI J, YIN M, LUKK M, JAHKOLA T, VIROLAINEN S, ORA A, UKKONEN E, SAKSELA O, HOLTTA E (2006). Switch to an invasive growth phase in melanoma is associated with tenascin- $C$, fibronectin, and procollagen-I forming specific channel structures for invasion. JPathol210:181-191.

KALLURI R (2003). Basement membranes: structure, assembly and role in tumour angiogenesis. Nat Rev Cancer 3: 422-433.

KIBBEY MC, GRANT DS, KLEINMAN HK (1992). Role of the SIKVAV site of laminin in promotion of angiogenesis and tumor growth - An in vivo matrigel model. J Nat Cancer Inst 84: 1633-1638.

KIDD KR, WILLIAMS SK (2004). Laminin-5-enriched extracellular matrix accelerates angiogenesis and neovascularization in association with ePTFE. J Biomed Mater Res A 69: 294-304.

KIDD KR, DAL PONTE D, STONE AL, HOYING JB, NAGLE RB, WILLIAMS SK (2005). Stimulated endothelial cell adhesion and angiogenesis with laminin-5 modification of expanded polytetrafluoroethylene. Tissue Eng 11: 1379-1391.

KIKKAWA Y, AKAOGI K, MIZUSHIMA H, YAMANAKA N, UMEDA M, MIYAZAKI K (1996). Stimulation of endothelial cell migration in culture by ladsin, a laminin-5-like cell adhesion protein. In vitro Cell Dev Biol-Animal 32: 46-52.

KIKKAWAY, TAKAHASHI N, MATSUDAY, MIWAT, AKIZUKIT, KATAOKAA, NOMIZU $M$ (2009). The influence of synthetic peptides derived from the laminin [alpha]1 chain on hepatocyte adhesion and gene expression. Biomaterials 30: 6888-6895.

KINGSLEY K, RUST WL, HUFF JL, SMITH RC, PLOPPER GE (2002a). PDGF-BB enhances expression of, and reduces adhesion to, laminin-5 in vascular smooth muscle cells. Biochem Biophys Res Commun 294: 1017-1022.

KINGSLEY K, HUFF JL, RUST WL, CARROLL K, MARTINEZ AM, FITCHMUN M, PLOPPER GE (2002b). ERK1/2 mediates PDGF-BB stimulated vascular smooth muscle cell proliferation and migration on laminin-5. Biochem Biophys Res Commun 293: 1000-1006.

KLEINMAN HK, MARTIN GR (2005). Matrigel: Basement membrane matrix with biological activity. Sem. Cancer Biol. 15: 378-386.

KUBOTA Y, KLEINMAN HK, MARTIN GR, LAWLEY TJ (1988). Role of laminin and basement membrane in the morphological differentiation of human endothelial cells into capillary-like structures. J Cell Biol 107: 1589-1598.

KUCERAT, STRILICB, REGENERK, SCHUBERTM, LAUDET V, LAMMERTE (2009). Ancestral vascular lumen formation via basal cell surfaces. PLOS ONE 4: e4132.

KUCERA T, LAMMERT E (2009). Ancestral vascular tube formation and its adoption by tumors. Biol Chem 390: 985-994.

KURATOMI Y, NOMIZU M, NIELSEN PK, TANAKA K, SONG SY, KLEINMAN HK YAMADAY (1999). Identification of metastasis-promoting sequences in the mouse laminin alpha-1 chain. Exp Cell Res 249: 386-395

LI J, ZHOU L, TRAN HT, CHEN Y, NGUYEN NE, KARASEK MA, MARINKOVICH MP (2006). Overexpression of laminin-8 in human dermal microvascular endothelia cells promotes angiogenesis-related functions. J Invest Dermatol 126: 432-440.

LIS, EDGARD, FASSLERR, WADSWORTHW, YURCHENCO PD (2003). The role of laminin in embryonic cell polarization and tissue organization. Dev Cell4:613-624.

LITJENS SHM, de PEREDA JM, SONNENBERG A (2006). Current insights into the formation and breakdown of hemidesmosomes. Trends Cell Biol 16: 376-383.

LJUBIMOVA JY, LAKHTER AJ, LOKSH A, YONG WH, RIEDINGER MS, MINER JH, SOROKIN LM, LJUBIMOV AV, BLACK KL (2001). Overexpression of alpha4 chain-containing laminins in human glial tumors identified by gene microarray analysis. Cancer Res 61: 5601-5610.

LJUBIMOVA JY, FUJITA M, KHAZENZON NM, LJUBIMOV AV, BLACK KL (2006). Changes in laminin isoforms associated with brain tumor invasion and angiogenesis. Front Biosci 11: 81-88

LUGASSY CM, BARNHILL RLM (2007). Angiotropic melanoma and extravascular migratory metastasis: A review. Adv Anat Pathol 14: 195-201.

LUGASSY C, TORRES-MUNOZ JE, KLEINMAN HK, GHANEM G, VERNON S BARNHILL RL (2009). Overexpression of malignancy-associated laminins and laminin receptors by angiotropic human melanoma cells in a chick chorioallantoic membrane model. J Cutan Pathol 36: 1237-1243.

LUTOLF MP, HUBBELL JA (2005). Synthetic biomaterials as instructive extracellular microenvironments for morphogenesis in tissue engineering. Nat Biotech23:47-55

MALINDA KM, NOMIZU M, CHUNG M, DELGADO M, KURATOMI Y, YAMADA Y, KLEINMAN HK, PONCE ML (1999). Identification of laminin $\alpha 1$ and $\beta 1$ chain peptides active for endothelial cell adhesion, tube formation, and aortic sprouting FASEB J 13: 53-62.

MANIOTIS AJ, FOLBERG R, HESS A, SEFTOR EA, GARDNER LMG, PE'ER J, TRENT JM, MELTZER PS, HENDRIX MJC (1999). Vascular channel formation by human melanoma cells in vivo and in vitro: vasculogenic mimicry. Am J Pathol 155: 739-752.

MINER JH, CUNNINGHAM J, SANES JR (1998). Roles for laminin in embryogenesis: Exencephaly, syndactyly, and placentopathy in mice lacking the laminin alpha 5 chain. J Cell Biol 143: 1713-1723.

MINER JH, YURCHENCO PD (2004). Laminin functions in tissue morphogenesis. Annu Rev Cell Dev Biol 20: 255-284

MINER JH, LI C, MUDD JL, GO G, SUTHERLAND AE (2004). Compositional and structural requirements for laminin and basement membranes during mouse embryo implantation and gastrulation. Development 131: 2247-2256.

MINERJH (2008). Laminins and their roles in mammals. Microsc Res Tech71:349-356.

MOCHIZUKI M, PHILP D, HOZUMI K, SUZUKI N, YAMADA Y, KLEINMAN HK, NOMIZU M (2007). Angiogenic activitiy of syndecan-binding laminin peptide AG73 (RKRLQVQLSIRT). Arch. Biochem. Biophys. 459: 249-255.

NAKAMURAM, MIE M, MIHARA H, NAKAMURAM, KOBATAKE E (2008). Construction of multi-functional extracellular matrix proteins that promote tube formation of endothelial cells. Biomaterials 29: 2977-2986.

NAKAMURAM, YAMAGUCHIK, MIE M, NAKAMURAM, AKITAK, KOBATAKE E (2009). Promotion of angiogenesis by an artificial extracellular matrix protein containing the laminin-1 derived IKVAV sequence. Bioconjugate Chemistry 20: 1759-1764.

NIKOLOVA G, JABS N, KONSTANTINOVA I, DOMOGATSKAYAA, TRYGGVASON K, SOROKIN L, FASSLER R, GU G, GERBER HP, FERRARA N (2006). The vascular basement membrane: a niche for insulin gene expression and [beta] 
cell proliferation. Dev Cell 10: 397-405.

NOMIZU M, KIM WH, YAMAMURA K, UTANI A, SONG SY, OTAKA A, ROLLER PP, KLEINMAN HK, YAMADAY (1995). Identification of cell binding sites in the laminin $\alpha 1$ chain carboxyl-terminal globular domain by systematic screening of synthetic peptides. J Biol Chem 270: 20583-20590.

NOMIZU M, KURATOMIY, MALINDAKM, SONG SY, MIYOSHIK, OTAKAA, POWELL SK, HOFFMAN MP, KLEINMAN HK, YAMADA Y (1998). Cell binding sequences in mouse laminin $\alpha 1$ chain. J Biol Chem 273: 32491-32499.

ORIAN-ROUSSEAU V, ABERDAM D, FONTAO L, CHEVALIER L, MENEGUZZI G, KEDINGER M, SIMON-ASSMANN P (1996). Developmental expression of laminin-5 and HD1 in the intestine: Epithelial to mesenchymal shift for the laminin $\gamma 2$ chain subunit deposition. Dev Dyn 206: 12-23.

PASSANITI A, TAYLOR RM, PILI R, GUO Y, LONG PV, HANEY JA, PAULY RR, GRANT DS, MARTIN GR (1992). A simple, quantitative method for assessing angiogenesis and antiangiogenic agents using reconstituted basement membrane, heparin, and fibroblast growth factor. Lab Invest 67: 519-528.

PATARROYO M, TRYGGVASON K, VIRTANEN I (2002). Laminin isoforms in tumor invasion, angiogenesis and metastasis. Semin Cancer Biol 12: 197-207.

PAULY RR, PASSANITI A, CROW M, KINSELLA JL, PAPADOPOULOS N, MONTICONE R, LAKATTA EG, MARTIN GR (1992). Experimental models that mimic the differentiation and dedifferentiation of vascular cells. Circulation 86: III68-73.

PONCE ML, KLEINMAN HK (2003). Identification of redundant angiogenic sites in laminin alpha1 and gamma1 chains. Exp Cell Res 285: 189-195.

PONCE ML, NOMIZU M, DELGADO MC, KURATOMI Y, HOFFMAN MP, POWELL S, YAMADA Y, KLEINMAN HK, MALINDA KM (1999). Identification of endothelial cell binding sites on the laminin gamma1 chain. Circ Res 84: 688-694.

PONCE ML, NOMIZU MOTO, KLEINMAN HK (2001). An angiogenic laminin site and its antagonist bind through the alphavbeta3 and alpha5beta1 integrins. FASEB J 15: 1389-1397.

PONCE ML, HIBINO S, LEBIODA AM, MOCHIZUKI M, NOMIZU M, KLEINMAN HK (2003). Identification of a potent peptide antagonist to an active laminin-1 sequence that blocks angiogenesis and tumor growth. Cancer Res63:5060-5064.

RISAU W, FLAMME I (1995). Vasculogenesis. Annu Rev Cell Dev Biol 11: 73-91.

ROZARIO T, DESIMONE DW (2010). The extracellular matrix in development and morphogenesis: A dynamic view. Dev Biol 341: 126-140.

SAKAMOTO N, IWAHANA M, TANAKA NG, OSADA Y (1991). Inhibition of angiogenesis and tumor growth by a synthetic laminin peptide, CDPGYIGSR-NH2. Cancer Res 51: 903-906.

SASAKIT, GILTAYR, TALTSU, TIMPLR, TALTS JF (2002). Expression and distribution of laminin alpha1 and alpha2 chains in embryonic and adult mouse tissues: an immunochemical approach. Exp Cell Res 275: 185-199.

SCHNAPER HW, KLEINMAN HK, GRANT DS (1993). Role of laminin in endothelial cell recognition and differentiation. Kidney Int 43: 20-25.

SEFTOR RE, SEFTOR EA, KOSHIKAWAN, MELTZER PS, GARDNER LM, BILBAN M, STETLER-STEVENSON WG, QUARANTA V, HENDRIX MJ (2001). Cooperative interactions of laminin 5 gamma2 chain, matrix metalloproteinase-2, and membrane type-1-matrix/metalloproteinase are required for mimicry of embryonic vasculogenesis by aggressive melanoma. Cancer Res 61: 6322-6327.

SEMINAEV, BOSENKO DV, ZINKEVICHNC, SOULES KA, HYDE DR, VIHTELICTS, WILLER GB, GREGG RG, LINK BA (2006). Mutations in laminin alpha1 result in complex, lens-independent ocular phenotypes in zebrafish. Dev Biol 299: 63-77.

SILVA R, D'AMICO G, HODIVALA-DILKE KM, REYNOLDS LE (2008). Integrins: the keys to unlocking angiogenesis. Arterioscler Thromb Vasc Biol 28: 1703-1713.

SIMO P, SIMON-ASSMANN P, BOUZIGES F, LEBERQUIER C, KEDINGER M,
EKBLOM P, SOROKIN L (1991). Changes in the expression of laminin during intestinal development. Development 112: 477-487.

SIMON-ASSMANN, P., SPENLE C., LEFEBVRE O., and KEDINGER, M. (2010). The role of the basement membrane as a modulator of intestinal epithelial-mesenchymal interactions. In Progress in Molecular Biology and Translational Science-Molecular Biology of Digestive Organs (Ed. P.M. Conn). Academic Press 96, pp. 175-206.

SIXT M, ENGELHARDT B, PAUSCH F, HALLMANN R, WENDLER O, SOROKIN LM (2001). Endothelial cell laminin isoforms, laminins 8 and 10, play decisive roles in $T$ cell recruitment across the blood-brain barrier in experimental autoimmune encephalomyelitis. J Cell Biol 153: 933-946.

SOROKIN LM, PAUSCH F, FRIESER M, KROGER S, OHAGE E, DEUTZMANN $R$ (1997). Developmental regulation of the laminin $\alpha 5$ chain suggests a role in epithelial and endothelial cell maturation. Dev Biol 189: 285-300.

STACK MS, GRAY RD, PIZZO SV (1993). Modulation of murine B16F10 melanoma plasminogen activator production by a synthetic peptide derived from the laminin A chain. Cancer Res 53: 1998-2004.

STRATMANAN, MALOTTE KM, MAHAN RD, DAVIS MJ, DAVIS GE (2009). Pericyte recruitment during vasculogenic tube assembly stimulates endothelial basement membrane matrix formation. Blood 114: 5091-5101.

STREULI CH, SCHMIDHAUSER C, BAILEY N, YURCHENCO P, SKUBITZ APN, ROSKELLEY C, BISSELL MJ (1995). Laminin mediates tissue-specific gene expression in mammary epithelia. J Cell Biol 129: 591-603.

SUZUKI N, YOKOYAMA F, NOMIZU M (2005). Functional sites in the laminin alpha chains. Connect Tissue Res 46: 142-152.

THYBOLL J, KORTESMAA J, CAO R, SOININEN R, WANG L, IIVANAINEN A, SOROKIN L, RISLING M, CAO Y, TRYGGVASON K (2002). Deletion of the laminin alpha4 chain leads to impaired microvessel maturation. Mol CellBiol22: 1194-1202.

TIMPL R, ROHDE H, ROBEY PG, RENNARD SI, FOIDART JM, MARTIN GR (1979). Laminin. Aglycoprotein from basement membranes. J Biol Chem 254: 9933-9937.

VAINIONPAAN, KIKKAWAY, LOUNATMAAK, MINER JH, ROUSSELLE P, VIRTANEN I (2006). Laminin-10 and Lutheran blood group glycoproteins in adhesion of human endothelial cells. Am J Physiol Cell Physiol 290: C764-C775.

VIRTANEN I, GULLBERG D, RISSANEN J, KIVILAAKSO E, KIVILUOTO T, LAITINEN LA, LEHTO VP, EKBLOM P (2000). Laminin $\alpha 1$-chain shows a restricted distribution in epithelial basement membranes of fetal and adult human tissues. Exp Cell Res 257: 298-309.

VON TELL D, ARMULIK A, BETSHOLTZ C (2006). Pericytes and vascular stability. Exp Cell Res 312: 623-629.

WANG B, SUN J, KITAMOTO S, YANG M, GRUBB A, CHAPMAN HA, KALLURI $\mathrm{R}$, SHI GP (2006a). Cathepsin S controls angiogenesis and tumor growth via matrix-derived angiogenic factors. J Biol Chem 281: 6020-6029.

WANG J, HOSHIJIMA M, LAM J, ZHOU Z, JOKIEL A, DALTON ND, HULTENBY K, RUIZ-LOZANOP, ROSSJ, TRYGGVASONK, CHIEN KR (2006b). Cardiomyopathy associated with microcirculation dysfunction in laminin alpha4 chain-deficient mice. J Biol Chem 281: 213-220.

WU C, IVARS F, ANDERSON P, HALLMANN R, VESTWEBER D, NILSSON P, ROBENEK H, TRYGGVASON K, SONG J, KORPOS E, LOSER K, BEISSERT S, GEORGES-LABOUESSE E, SOROKIN LM (2009). Endothelial basement membrane laminin alpha5 selectively inhibits $T$ lymphocyte extravasation into the brain. Nat Med 15: 519-527.

YURCHENCO PD, PATTON BL (2009). Developmental and pathogenic mechanisms of basement membrane assembly. Curr Pharm Des 15: 1277-1294.

ZHOU Z, DOI M, WANG J, CAO R, LIU B, CHAN KM, KORTESMAA J, SOROKIN L, CAO Y, TRYGGVASON K (2004). Deletion of laminin-8 results in increased tumor neovascularization and metastasis in mice. Cancer Res 64: 4059-4063. 


\section{Further Related Reading, published previously in the Int. J. Dev. Biol.}

Insulin-like growth factor-2 regulates early neural and cardiovascular system development in zebrafish embryos Lori Hartnett, Catherine Glynn, Catherine M. Nolan, Maura Grealy and Lucy Byrnes Int. J. Dev. Biol. (2010) 54: 573-583

The seminal work of Werner Risau in the study of the development of the vascular system Domenico Ribatti

Int. J. Dev. Biol. (2010) 54: 567-572

Estrogen regulation of placental angiogenesis and fetal ovarian development during primate pregnancy Eugene D. Albrecht and Gerald J. Pepe Int. J. Dev. Biol. (2010) 54: 397-407

Uteroplacental vascular development and placental function: an update Lawrence P. Reynolds, Pawel P. Borowicz, Joel S. Caton, Kimberly A. Vonnahme, Justin S. Luther, David S. Buchanan, Shireen A. Hafez, Anna T. Grazul-Bilska and Dale A. Redmer Int. J. Dev. Biol. (2010) 54: 355-365

Critical growth factors and signalling pathways controlling human trophoblast invasion Martin Knöfler Int. J. Dev. Biol. (2010) 54: 269-280

Over-expression of thymosin beta4 promotes abnormal tooth development and stimulation of hair growth Hee-Jae Cha, Deborah Philp, Soo-Hyun Lee, Hye-Sung Moon, Hynda K. Kleinman and Takashi Nakamura Int. J. Dev. Biol. (2010) 54: 135-140

The contribution of Roberto Montesano to the study of interactions between epithelial sheets and the surrounding extracellular matrix

Domenico Ribatti

Int. J. Dev. Biol. (2010) 54: 1-6

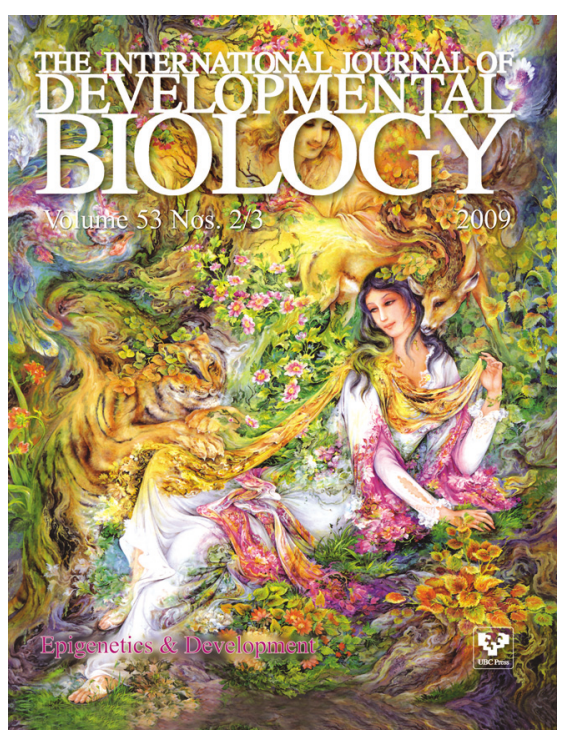

5 yr ISI Impact Factor $(2009)=3.253$

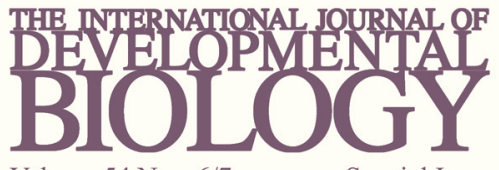

Volume 54 Nos. 6/7
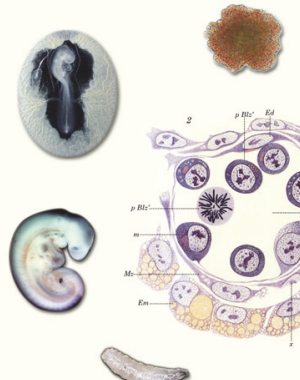

Special Issue

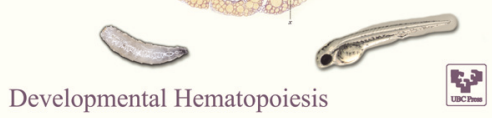

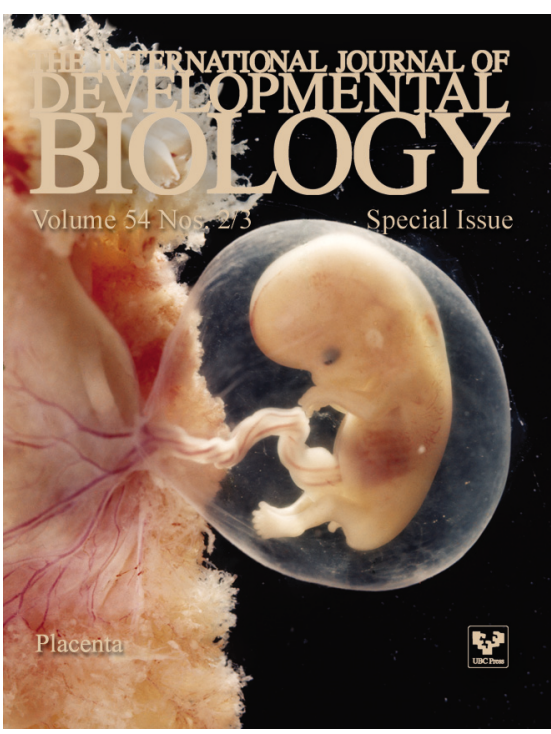

